\title{
確率分布の推定母数の不確定性評価法

\author{
UNCERTAINTY MEASUREMENT ON POPULATION \\ PARAMETERS OF PROBABILITY DISTRIBUTION
}

\author{
寒川典昭*.荒木正夫** ・渡辺輝 彦*** \\ By Noriaki SOGAWA, Masao ARAKI and Teruhiko WATANABE
}

\begin{abstract}
This paper discusses the uncertainty of the estimated population parameters in the hydrologic frequency analysis. Firstly, the changes of the distribution shape and the probable variate of a fixed recurrence interval are investigated using the observed hydrologic data. Next, when the population parameters of the normal distribution are regarded as the random variables, the method of estimation of the decrease degree of the uncertainty, which is measured by the entropy of the distribution in unknown expectation-known variance and unknown expectation-unknown variance, is developed in some detail. Besides, applying this method of estimation to the observed hydrologic data, the validity of this method is investigated. Finally, the possibility of the application of this method to the non-normal population is suggested briefly.
\end{abstract}

Keywords : uncertainty, population parameters, normal distribution, entropy

\section{1. まえがき}

治水・利水計画を策定するにあたっては，対象となる 水文観測資料を用いて頻度解析を行い, 計画に必要な確 率水文量を算定することが要求される．信頼性の高い水 工計画を策定するためには，確率水文量の精度を高める 必要があり, 従来より水文頻度解析に必要な資料の収集 および解析手法の確立に多大の努力が重ねられてきた. その結果, 多くの確率分布が水文学に導入され, それら の分布の特徴が解明された。 また，パラメータ一同定法 は, モ一メント法, 最尤法を基礎として, できるだけ母 集団に合う母数の推定法が提示された。 しかし，水文資 料は小標本である場合が多く，解析に用いられる確率分 布の決定に際しても経験的に判断されているにすぎず, 求められた確率水文量には多くの不確定さが内在するこ とは否定できない．このような現状から確率水文量の精 度をさらに高める努力がなされなければならないことは もちろんであるが，小標本の資料の使用を余儀なくされ ている以上, どうしてもぬぐいされない不確定さを評価

* 正会員 工修 信州大学助手 工学部土木工学科 （テ380 長野市若里 500 )

** 正会員 工博 信州大学教授 工学部土木工学科 (同上)

*** 工修 (株)オービック (研究当時信州大学大学院工学研 究科学生) ( 103 中央区日本橋室町 4-2 東邦生命ビル)
しておくことはきわめて重要である.

確率水文量の不確定さを考えた場合，大別して $2 つ に$ 分類される. 1 つは分布形决定に関する不確定さであり, 他の 1 つは分布形が決定された後も存在する推定母数に 関する不確定さである.

水文頻度解析には，（ｉ）正規分布を前提とした分布, （ii）ガンマ分布を前提にした分布，および（iii）極值 分布が採用されている. ところが，対象とする水文量が いかなる母集団に属するかという問題に対しては，単に 経験的に，たとえば確率紙上へのプロットから判断され ているにすぎず，そこには理論的な根拠，あるいは思想 的な妥当性は存在していなかった.

このような問題に対して, 高棹・池淵 ${ }^{1)}$ は, 平均指定 の最大エントロピー分布は指数分布, 分散指定の場合は 正規分布になることに着目し，時間単位別の降水量が平 均と標準偏差のどちらが安定しているかを検討して, 従 う分布形の理論的な説明を試みた. Sonuga ${ }^{21,3)}$ は, 標 本から得られる情報は 2 次までのモーメントの形で取り 入れ, それ以外はエントロピーが最大となる分布を求め た. われわれ(4), () は，情報理論の分野で Wragg \& Dowson $^{6)}$ が示した展開法を導入し, 任意次数までのモ一 メントを制約条件とした 1 変数最大エントロピー分布の 特性を研究し, 水文学への適用をはかった.さらに, そ 
れを 2 変数 ${ }^{7)}$ から多変数 ${ }^{8)}$ へと拡張し，同様な検討を行っ た.

ところが，分布形が決定されたとしても，それがいか なる資料から母数推定がなされたものであるかにより， 確率水文量の信頼性が大きく異なってくる．にもかかわ らず, ひとたび頻度解析が行われ, 確率水文量が決定さ れると，その水文量に従って水工計画が実施され，その 水文量の信頼性がほとんど理論的に吟味されていないの が実情である.

本稿は，このような推定母数に関する不確定性につい て，正規分布に基づいて議論したものである.

まず最初に，資料数の增加に伴う分布形および確率水 文量の変動を観測資料を用いて検討する. 次に，正規分 布を支配する母数を確率変数とみなして，平均未知，分 散既知の場合，および両者にも未知の場合について，資 料数の增加に伴う不確定性の減少度を, 推定母数の事後 分布のエントロピーの減少度という形で表現する方法を 提示・定式化する. 最後に, 実測水文資料に適用して本 法の妥当性を検証するとともに，非対称母集団に対する 適用性を示唆する.

\section{2. 分布形の変動}

\section{（1）対象水文資料}

水工計画上基本的な資料は，降水量および河川流量で ある. とりわけ，降水量は，水文資料の中で比較的よく 整備されていることもあり，水工計画上きわめて重要な 資料である. そのため，ここでは年降水量および年最大 日降水量を対象とする. もちろん，他の水文量について も同様な検討がなされ得ることはいうまでもない.

使用する観測資料は，長野県内の雨量観測所で得られ たものであり, 年降水量は 19 か所, 年最大日降水量は 28 か所である9 . Table 1 に観測所および観測資料数の 一覧表を揭げる. 資料数の相違は, 観測開始年の相違, 文献 9）編集後に一部の資料を追加したこと，および欠 測によって生じている.

観測資料には地域特性がみられ，平均年降水量は篠ノ 井が $936 \mathrm{~mm}$ で最も少なく, 野沢温泉の $1926 \mathrm{~mm}$ が最 も多くなっており, 19 地点の平均は $1221 \mathrm{~mm}$ であった. 平均年最大日降水量は中野が $58 \mathrm{~mm}$ で最も少なく, 大 町の $117 \mathrm{~mm}$ が最も多くなっており, 28 地点の平均は $70 \mathrm{~mm}$ であった.

地域間の相関をみると，年降水量の相関が大きい地点 間, たとえば松本と上田, 長野と上田等では年最大日降 水量の相関も大きく, 飯山之上田等の年降水量の相関が 小さいところでは年最大日降水量の相関も小さくなって いる. また，年最大日降水量は局所的な気象変化の影響 を受けやすいため，同一地点間では年降水量の相関より
Table 1 Gaging stations of precipitation and number of data (left : annual precipitation, right : annual maximum daily precipitation).

\begin{tabular}{lcc|lcc}
\hline $\begin{array}{l}\text { Gaging } \\
\text { stations }\end{array}$ & \multicolumn{2}{l|}{$\begin{array}{l}\text { Number } \\
\text { of data }\end{array}$} & $\begin{array}{l}\text { Gaging } \\
\text { stations }\end{array}$ & \multicolumn{2}{l}{$\begin{array}{l}\text { Number } \\
\text { of data }\end{array}$} \\
\hline Azumino & 56 & 70 & Nakano & 76 & 85 \\
Bessyo & 51 & 52 & Nojiri & - & 46 \\
Iiyama & 68 & 91 & Nozawaonsen & 65 & 69 \\
Iwamurada & 61 & 77 & Ömachi & 80 & 89 \\
Karuizawa & - & 59 & Ōtaki & - & 46 \\
Kawakami & - & 44 & Sakaki & - & 41 \\
Kinasa & 60 & 64 & Shinonoi & 67 & 78 \\
Kitamaki & 47 & 54 & Sugadaira & - & 57 \\
Kitashiro & - & 46 & Suzaka & 72 & 77 \\
Matumoto & 85 & 86 & Togakushi & - & 55 \\
Minamiotari & - & 72 & Toyoshina & 55 & 71 \\
Soga & 41 & 59 & Ueda & 88 & 89 \\
Nagano & 94 & 94 & Wada & 51 & 54 \\
Nakajo & 55 & 58 & Yashiro & 64 & 77 \\
\hline
\end{tabular}

小さくなっている.

どちらの資料においても，周期性や従属性は顥著に現 れていない。

\section{（2）分布形の変動}

ここでは, 年降水量の分布は正規分布, 年最大日降水量 の分布はグンベル分布を用い, 資料数の増加に伴う頻度 図, 適合された分布形および確率水文量の変動を検討す る.なお,資料は観測年の新しい順に 10 個刻みで増加させ， 分布の母数推定は積率法を用いた. 紙面の都合上, 以下の 図では一部の観測点についてのみ示すことにする.

a）年降水量（正規分布）

上述の 19 の観測所について資料数の増加に伴う頻度 図と分布形の変動の様子を描いた. 図一1に，その一例 として長野の場合を示す.

頻度図をみると, 資料数が 10 個, 20 個, 30 個と増加 するに伴い, 急激な変動を示しながらその形が整ってい く様子が䫓著に現われており, 資料数が 40 個以上にな るとその変動は比較的緩やかなものになる．このような 傾向は観測資料数の大小にかかわらず，19 の観測所の すべての地点においてみられる．あてはめた分布形も当 然のことながら資料数が 30 個程度の場合を境にして変 動の様子に違いがみられ, 資料数が少ない場合の変動は 激しく，多くなると安定してきていることがわかる.

次に, 長野, 松本, 上田の 3 つの観測所について, デー 夕数の増加に伴う 10 年, 30 年非超過確率水文量と 50 年, 100 年超過確率水文量の変動の様子を調べた. 図一 2 に，その一例として長野の場合を示す.

対象とする確率水文量や地点間での差異は大きいが, 長野ではデー夕数が 40 個ないし 50 個から, 振動しなが らも一定の値に収束していく傾向がみられる. 

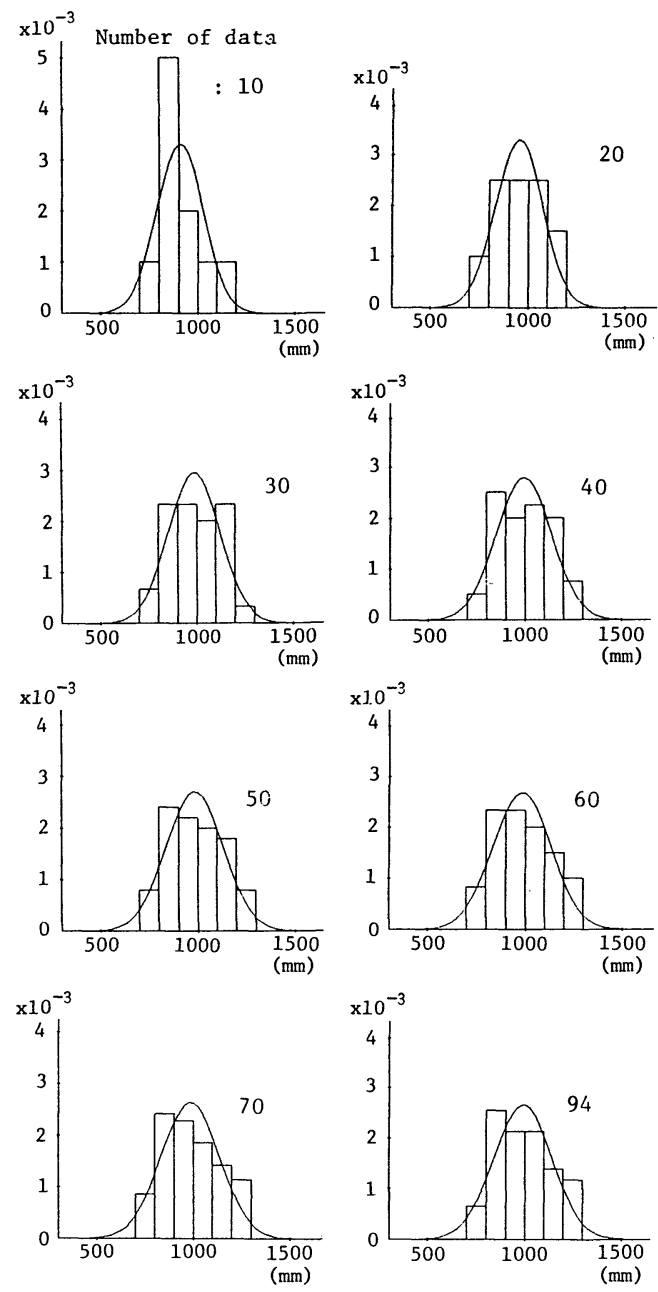

Fig. 1 Change of histogram and fitted normal p. d. f. for annual precipitation with increasing data (Nagano).

\section{b）年最大日降水量（グンベル分布）}

上述の 28 の観測所について資料数の増加に伴う頻度 図之分布形の変動の様子を描いた. 図一3に, その一例 として長野の場合を示す.

年降水量の場合と同様に, 頻度図および分布形は, 資 料数が 30 個程度以下の場合は大きく変動し, それを越 えると安定してきていることがわかる。

次に, 長野, 松本, 上田の 3 つの観測所について, デー 夕数の増加に伴う 50 年, 100 年超過確率水文量の変動 の様子を調べた．図一 4 に，その一例として長野の場合 を示す。

この場合, 3 地点ともに, 資料数が 30 個を越えると 50 年, 100 年超過確率水文量は安定してきている.

以上, 資料数の増加に伴う頻度図，分布形および確率 水文量の変動特性を検討したが，大部分は資料数が 30
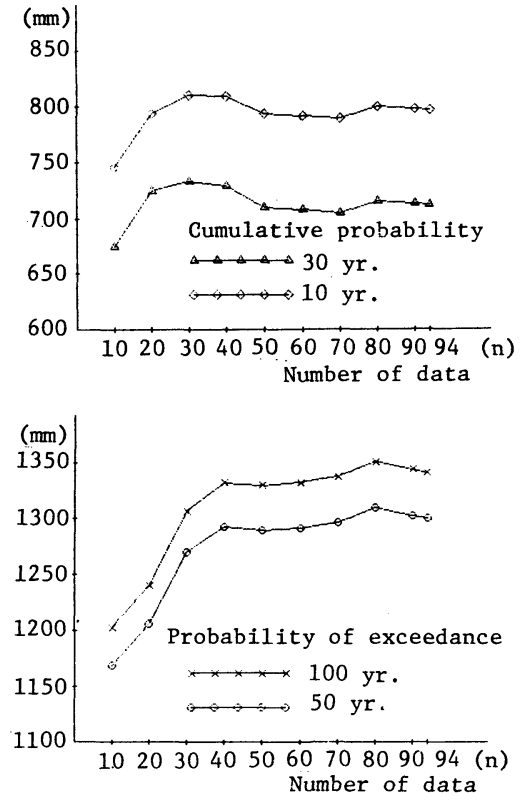

Fig. 2 Change of estimated variate to same fixed recurrence intervals with increasing data of annual precipitation (Nagano).

個ないし 40 個程度以上となると変動は小さくなり安定 してきていることがわかる，しかし，資料数が 80 個， 90 個程度あっても，分布形の変動，すなわち，推定母 数の不確定性が確率水文量に及ぼす影響は無視できない ことも付記する.

\section{3. 母数の不確定性とエントロピー}

与えられた確率分布が母集団の確率分布と一致してい るなら，母数の推定精度が確率水文量の信頼性を支配す る. 母数を確率変数と考えると, 母数の確率分布 ( 1 次 元あるいは多次元）の形状がシャープなほよ゙，その推定 精度が高くなることが予想される。 そこで，ここでは母 数の与えられた事前分布に対し，ベイズ論的立場から得 られた事後分布を示し，その分布のエントロピーを計算 可能な形に変換する.

なお，以下での議論は，基礎確率変数（以下では母数 を確率変数とみなしているため，それと区別する意味で 水文量を表現する確率変数を基礎確率変数とよぶことに する）が確率分布の中で最も基本となる正規分布に従う 場合に限った.

\section{（1）正規情報を取り入れた事後確率分布 ${ }^{10)}$}

末知な真の状態 $\varphi$ が状態空間 $\Phi$ の要素である場合, すなわち $\Phi=\{\varphi\}$ で与えられる場合を考える. $\varphi$ は次の a) では平均 $\theta$ を，b）では平均 $\theta$ と精度 $h$ を表現して いることになる. 

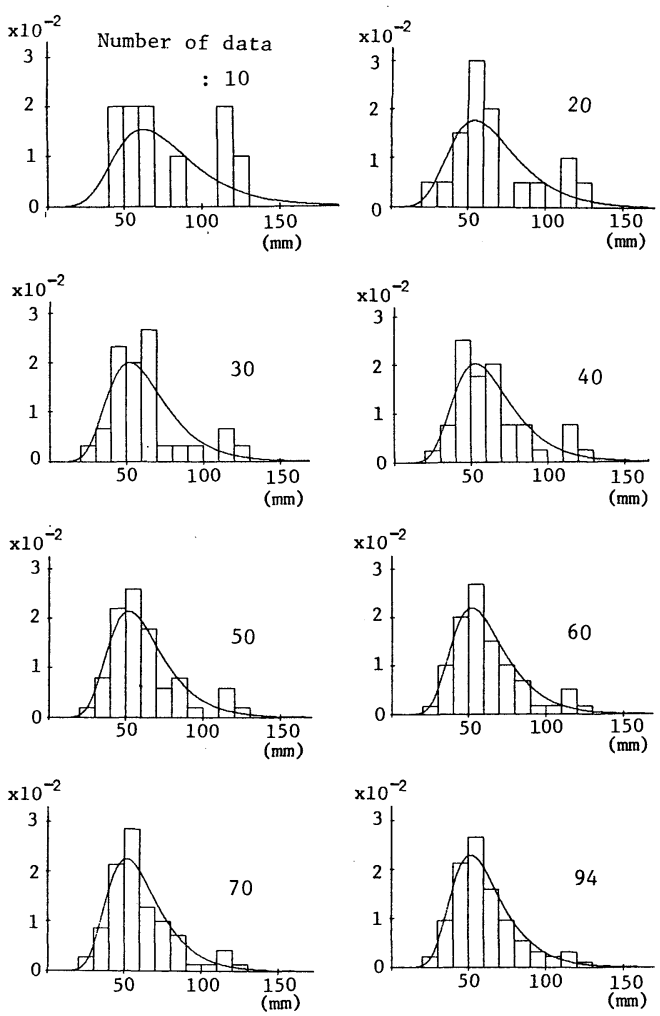

Fig. 3 Change of histogram and fitted Gumbel p.d.f. for annual maximum daily precipitation with increasing data (Nagano).

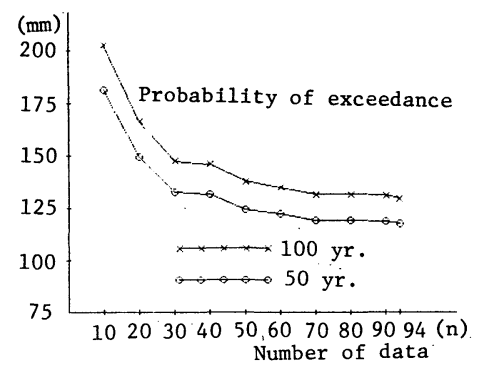

Fig. 4 Change of estimated variate to two fixed recurrence intervals with increasing data of annual maximum daily precipitation (Nagano).

a) 平均未知, 分散既知の場合

いま, $n$ 個の基礎確率変数からなる確率変量 $\widetilde{x}(n)=$ $\left(\tilde{x}_{1}, \tilde{x}_{2}, \cdots, \tilde{x}_{n}\right)$ (確率変数であることを明示するとき〜 を変数の上に付ける $)$ があり, $\tilde{x}_{i}(i=1,2, \cdots, n)$ は $\varphi \in \Phi$ が与えられたとき, 平均 $\theta$, 分散 $v$ をもって互い に独立に正規分布をするものと仮定する．このとき， $\tilde{x}(n)$ の実現值を知ることを大きさ $n$ の正規情報という. 正規情報が利用可能なとき, 平均 $\theta$ が末知で分散 $v$ が 既知の場合の $\tilde{\theta}$ の事前確率分布の密度関数 $\xi(\theta)$ が正規
分布 $N\left(m_{\theta}, v_{\theta}\right)$ で与えられるものとする.すすなお，

$$
\xi(\theta)=f_{N}\left(\theta \mid m_{\theta}, v_{\theta}\right)
$$

ここで， $f_{N}(\cdot)$ は正規分布の密度関数である.

このとき, $\tilde{x}(n)=x(n)$ が与えられての $\tilde{\theta}$ の事後確率 分布の密度関数 $\xi(\theta \mid x(n))$ は, ベイズ論的立場から次の 正規分布で与えられる.

$$
\xi(\theta \mid x(n))=f_{N}\left(\theta \mid m_{\theta \mid x(n)}, v_{\theta \mid x(n)}\right)
$$

ここで,

$$
\begin{aligned}
& m_{\theta \mid x(n)}=\frac{\frac{1}{v_{\theta}} m_{\theta}+\frac{n}{v} \bar{x}}{\frac{1}{v_{\theta}}+\frac{n}{v}}=\frac{m_{\theta} v+n \bar{x} v_{\theta}}{v+n v_{\theta}} \\
& \frac{1}{v_{\theta \mid x(n)}}=\frac{1}{v_{\theta}}+\frac{n}{v}, \quad v_{\theta \mid x(n)}=\frac{v v_{\theta}}{v+n v_{\theta}}
\end{aligned}
$$

b) 平均末知, 分散末知の場合

i）平均亡精度の同時事後確率分布

$\varphi \in \Phi$ が与えられたとき, $\tilde{x}_{i}(i=1,2, \cdots, n)$ は平 均 $\theta$, 精度 $h \equiv 1 / v$ をもって互いに独立に正規分布をす るものと仮定する. このとき, 平均 $\theta$, 精度 $h$ がとも に未知の場合の $(\tilde{\theta}, \tilde{h})$ の同時事前確率分布の密度関数 $\xi(\theta, h)$ が, $\alpha^{\prime}, \beta^{\prime}, n^{\prime}, \nu^{\prime}$ をパラメーターとする次の正 規一ガンマ分布で与えられるものとする.

$$
\begin{aligned}
\xi(\theta, h)= & \frac{n^{\prime / 2}}{(2 \pi)^{1 / 2}} \frac{1}{\Gamma\left(\nu^{\prime} / 2\right)}\left(\frac{1}{2} \beta^{\prime} \nu^{\prime}\right)^{\nu^{\prime / 2}} \\
& \cdot \exp \left\{-\frac{1}{2} n^{\prime} h\left(\theta-\alpha^{\prime}\right)^{2}\right\} \\
& \cdot \exp \left(-\frac{1}{2} \beta^{\prime} \nu^{\prime} h\right) h^{\left(\nu^{\prime}-1\right) / 2} \ldots . .
\end{aligned}
$$

ここで, $\Gamma(\cdot)$ はガンマ関数である.

このとき,

$$
\bar{x}=\frac{1}{n} \sum_{i=1}^{n} x_{i}, \quad S=\frac{1}{n-1} \sum_{i=1}^{n}\left(x_{i}-\bar{x}\right)^{2}
$$

で与えられる $(\theta, h)$ に関する $\tilde{x}(n)$ に基づく十分統計量 を $\tilde{\bar{x}}, \tilde{S}$ とすると, $\tilde{\bar{x}}=\bar{x}, \tilde{S}=S$ が得られた後の $(\tilde{\theta}, \tilde{h})$ の同時事後確率分布の密度関数 $\xi(\theta, h \mid x(n))$ もやはり ベイズ論的立場から正規一ガンマ分布で与えられ，その パラメーターは次式から算定される.

$$
\begin{aligned}
& \alpha^{\prime \prime}=\frac{n^{\prime} \alpha^{\prime}+n \bar{x}}{n^{\prime}+n} \\
& n^{\prime \prime}=n^{\prime}+n \\
& \beta^{\prime \prime}=\frac{\left(\nu^{\prime} \beta^{\prime}+n^{\prime} \alpha^{\prime 2}\right)+\left(\nu S+n \bar{x}^{2}\right)-n^{\prime \prime} \alpha^{\prime 2}}{\nu^{\prime}+n} \\
& \nu^{\prime \prime}=\nu^{\prime}+n \\
& \text { ここで, }
\end{aligned}
$$

$$
\nu=n-1 \text {. }
$$

ii）平均に関する周辺事後確率分布

$(\tilde{\theta}, \tilde{h})$ の同時事前確率分布が式（4) に示される正規 一ガンマ分布であるとする.このとき, 式 ( 5 ) より $\tilde{\bar{x}}$ $=\bar{x}, \tilde{S}=S$ が得られた後の $\tilde{\theta}$ の周辺事後確率分布の密 
度関数 $\xi_{\theta}(\theta \mid x(n))$ は, $\alpha^{\prime \prime}, n^{\prime \prime} / \beta^{\prime \prime}, \nu^{\prime \prime}$ をパラメーターと

する一般化されたスチューデント分布

（補遺 1 参照）

$$
\begin{aligned}
\xi_{\theta}(\theta \mid x(n))= & \frac{\nu^{\prime \prime} \nu^{\prime \prime} / 2}{B\left(\frac{1}{2}, \frac{1}{2} \nu^{\prime \prime}\right)}\left\{\nu^{\prime \prime}+\frac{n^{\prime \prime}}{\beta^{\prime \prime}}\left(\theta-\alpha^{\prime \prime}\right)^{2}\right\}^{-\left(\nu^{\prime \prime}+1\right) / 2} \\
& \cdot\left(\frac{n^{\prime \prime}}{\beta^{\prime \prime}}\right)^{1 / 2} \cdots \ldots \ldots \ldots \ldots \ldots \ldots \ldots \ldots \ldots \ldots \ldots . . . \cdots
\end{aligned}
$$

で与えられる.ここに， $B(\cdot, \cdot \cdot)$ はベー夕関数であり, $\alpha^{\prime \prime}, \beta^{\prime \prime}, n^{\prime \prime}, \nu^{\prime \prime}$ は式（6）より決定される.

iii）精度に関する周辺事後確率分布

$(\tilde{\theta}, \tilde{h})$ の同時事前確率分布が式 (4) に示される正規 一ガンマ分布であるとする。 このとき, 式 (5) により $\tilde{x}=\bar{x}, \tilde{S}=S$ が得られた後の $\tilde{h}$ の周辺事後確率分布の 密度関数 $\xi_{h}(h \mid x(n))$ は

$$
\begin{aligned}
& \xi_{h}(h \mid x(n))=\frac{1}{\Gamma\left(\nu^{\prime \prime} / 2\right)}\left(\frac{1}{2} \beta^{\prime \prime} \nu^{\prime \prime}\right)^{\nu^{\prime \prime} / 2} h^{\nu \prime / 2-1} \\
& \cdot \exp \left(-\frac{1}{2} \beta^{\prime \prime} \nu^{\prime \prime} h\right)
\end{aligned}
$$

で与えられる.ここに， $\alpha^{\prime \prime}, \beta^{\prime \prime}, n^{\prime \prime}, \nu^{\prime \prime}$ は式 $(6)$ より 決定される.

\section{（2）事後確率分布のエントロピー}

a) 平均末知, 分散既知の場合

式 $(2)$ で示される $\tilde{\theta}$ の事後確率分布のエントロピー は

$$
\begin{aligned}
H(\theta)= & -\int_{-\infty}^{\infty} \xi(\theta \mid x(n)) \ln \xi(\theta \mid x(n)) d \theta \\
= & -\int_{-\infty}^{\infty} \frac{1}{\sqrt{2 \pi v_{\theta \mid x(n)}}} \exp \left\{-\frac{\left(\theta-m_{\theta}\right)^{2}}{2 v_{\theta \mid x(n)}}\right\} \\
& \cdot \ln \left[\frac{1}{\sqrt{2 \pi v_{\theta \mid x(n)}}} \exp \left\{-\frac{\left(\theta-m_{\theta}\right)^{2}}{2 v_{\theta \mid x(n)}}\right\}\right] d \theta \\
= & \ln \left(2 \pi e v_{\theta \mid x(n)}\right)^{1 / 2}
\end{aligned}
$$

b) 平均未知, 分散未知の場合

i) 平均之精度の同時事後確率分布のエントロピー

式 $(6)$ をパラメーターとする $(\tilde{\theta}, \tilde{h})$ の同時事後確 率分布のエントロピーは

$$
\begin{aligned}
H(\theta, h)= & -\int_{0}^{\infty} \int_{-\infty}^{\infty} \xi(\theta, h \mid x(n)) \ln \xi(\theta, h \mid x(n)) d \theta d h \\
= & -\int_{0}^{\infty} \int_{-\infty}^{\infty} \frac{n^{\prime \prime 1 / 2}}{(2 \pi)^{1 / 2}} \frac{1}{\Gamma\left(\nu^{\prime \prime} / 2\right)}\left(\frac{1}{2} \beta^{\prime \prime} \nu^{\prime \prime}\right)^{\nu^{\prime \prime} / 2} \\
& \cdot \exp \left\{-\frac{1}{2} n^{\prime \prime} h\left(\theta-\alpha^{\prime \prime}\right)^{2}\right\} \\
& \cdot \exp \left(-\frac{1}{2} \beta^{\prime \prime} \nu^{\prime \prime} h\right) h^{\left(\nu^{\prime \prime}-1\right) / 2} \\
& \cdot \ln \left[\frac{n^{\prime \prime 1 / 2}}{(2 \pi)^{1 / 2}} \frac{1}{\Gamma\left(\nu^{\prime \prime} / 2\right)}\left(\frac{1}{2} \beta^{\prime \prime} \nu^{\prime \prime}\right)^{\nu^{\prime \prime} / 2}\right. \\
& \cdot \exp \left\{-\frac{1}{2} n^{\prime \prime} h\left(\theta-\alpha^{\prime \prime}\right)^{2}\right\} \\
& \left.\cdot \exp \left(-\frac{1}{2} \beta^{\prime \prime} \nu^{\prime \prime} h\right) h^{\left(\nu^{\prime \prime}-1\right) / 2}\right] d \theta d h \\
= & -\ln A+B\left\{1-\psi\left(B+\frac{1}{2}\right)+\ln C\right\}+1
\end{aligned}
$$

ここで,

$$
\begin{aligned}
& A=\frac{n^{\prime \prime 1 / 2}}{(2 \pi)^{1 / 2}} \frac{1}{\Gamma\left(\nu^{\prime \prime} / 2\right)}\left(\frac{1}{2} \beta^{\prime \prime} \nu^{\prime \prime}\right)^{\nu^{\prime \prime} / 2} \\
& B=\left(\nu^{\prime \prime}-1\right) / 2 \\
& C=\beta^{\prime \prime} \nu^{\prime \prime} / 2
\end{aligned}
$$

であり, $\psi(\cdot)$ はディガンマ関数である.

ii）平均に関する周辺事後確率分布のエントロピー 式（8）で示される $\tilde{\theta}$ の事後確率分布のエントロピー は

$$
\begin{aligned}
H_{\theta}(\theta)= & -\int_{-\infty}^{\infty} \xi_{\theta}(\theta \mid x(n)) \ln \xi_{\theta}(\theta \mid x(n)) d \theta \\
= & -\int_{-\infty}^{\infty} \frac{\nu^{\prime \prime \prime} \nu^{\prime \prime} / 2}{B\left(1 / 2, \nu^{\prime \prime} / 2\right)}\left\{\nu^{\prime \prime}+\frac{n^{\prime \prime}}{\beta^{\prime \prime}}\left(\theta-\alpha^{\prime \prime}\right)^{2}\right\}^{-\left(\nu^{\prime \prime}+1\right) / 2} \\
& \cdot\left(\frac{n^{\prime \prime}}{\beta^{\prime \prime}}\right)^{1 / 2} \ln \left[\frac { \nu ^ { \prime \prime } \nu ^ { \prime \prime } / 2 } { B ( 1 / 2 , \nu ^ { \prime \prime } / 2 ) } \left\{\nu^{\prime \prime}+\frac{n^{\prime \prime}}{\beta^{\prime \prime}}\right.\right. \\
& \left.\left.\cdot\left(\theta-\alpha^{\prime \prime}\right)^{2}\right\}^{-\left(\nu^{\prime \prime}+1\right) / 2}\left(\frac{n^{\prime \prime}}{\beta^{\prime \prime}}\right)^{1 / 2}\right] d \theta=-\ln D+D E J_{\theta}
\end{aligned}
$$

(補遺 2 参照)

ここで,

$$
\begin{aligned}
& D=\frac{\nu^{\prime \prime \nu} / 2}{B\left(1 / 2, \nu^{\prime \prime} / 2\right)}\left(\frac{\nu^{\prime \prime}}{\beta^{\prime \prime}}\right)^{1 / 2} \\
& E=\left(\nu^{\prime \prime}+1\right) / 2 \\
& J_{\theta}=\int_{-\infty}^{\infty} \frac{\ln \left\{\nu^{\prime \prime}+\frac{n^{\prime \prime}}{\beta^{\prime \prime}}\left(\theta-\alpha^{\prime \prime}\right)^{2}\right\}}{\left\{\nu^{\prime \prime}+\frac{n^{\prime \prime}}{\beta^{\prime \prime}}\left(\theta-\alpha^{\prime \prime}\right)^{2}\right\}^{E}} d \theta
\end{aligned}
$$

iii）精度に関する周辺事後確率分布のエントロピー 式 (9) で示される $\tilde{h}$ の事後確率分布のエントロピー は

$$
\begin{aligned}
H_{h}(h)= & -\int_{0}^{\infty} \xi_{h}(h \mid x(n)) \ln \xi_{h}(h \mid x(n)) d h \\
= & -\int_{0}^{\infty} \frac{1}{\Gamma\left(\nu^{\prime \prime} / 2\right)}\left(\frac{1}{2} \beta^{\prime \prime} \nu^{\prime \prime}\right)^{\nu^{\prime \prime} / 2} h^{\nu^{\prime \prime} / 2-1} \\
& \cdot \exp \left(-\frac{1}{2} \beta^{\prime \prime} \nu^{\prime \prime} h\right) \ln \left\{\frac{1}{\Gamma\left(\nu^{\prime \prime} / 2\right)}\right. \\
& \left.\cdot\left(\frac{1}{2} \beta^{\prime \prime} \nu^{\prime \prime}\right)^{\nu^{\prime \prime} / 2} h^{\nu^{\prime \prime} / 2-1} \exp \left(-\frac{1}{2} \beta^{\prime \prime} \nu^{\prime \prime} h\right)\right\} d h \\
= & -\ln F+G\{1-\psi(G+1)+\ln C\}+1 \cdots \cdots(15
\end{aligned}
$$

（補遺 3 参照）

ここで,

$$
\begin{aligned}
& F=\frac{1}{\Gamma\left(\nu^{\prime \prime} / 2\right)}\left(\frac{1}{2} \beta^{\prime \prime} \nu^{\prime \prime}\right)^{\nu^{\prime \prime} / 2} \\
& G=\nu^{\prime \prime} / 2-1
\end{aligned}
$$

\section{4. 実測資料への適用と考察}

\section{（1）平均末知, 分散既知の場合}

式 $(3)$ の 2 番目の式において, $v_{\theta}$ は $\theta$ の分散に関 する事前情報であり，また $v$ は既知で一定としている 
から，これらの値を与えることにより，式（10）は資料 数 $n$ の関数として計算可能になる. しかしながら， $v_{\theta}$, $v$ は主観的に与えねばならず，その值によって $H(\theta)$ の 值は異なってくる.そこで，われわれはそれらを次のよ うにそれぞれ 5 種類考え，その組合せ（計 25 個）ごと にエントロピーを算定した。

$$
\begin{aligned}
v_{\theta}= & \frac{1}{5} \frac{v^{\prime}}{n_{\max } / 2}, \frac{1}{3} \frac{v^{\prime}}{n_{\max } / 2}, \frac{v^{\prime}}{n_{\max } / 2} \\
& \frac{3 v^{\prime}}{n_{\max } / 2}, \frac{5 v^{\prime}}{n_{\max } / 2} \\
v= & v^{\prime} / 5, v^{\prime} / 3, v^{\prime}, 3 v^{\prime}, 5 v^{\prime}
\end{aligned}
$$

ここで， $n_{\text {max }}$ は最大観測資料数， $v^{\prime}$ は $n_{\max }$ での資料 に関する分散である。

式 (3) と式 (10) から, 資料数が増加するとエント ロピーが減少することは容易にわかるが， $v_{\theta}$ と $v$ の組 合せも考慮してグラフ化した一例が図一5である. どの 地点でも， $v_{\theta}$ および $v$ の值が大きいほどエントロピー の值が大きくなり, 資料数が小さいほどエントロピーの 低下分が大きくなっていることがわかる．また， $v_{\theta}$ が 小さく $v$ が大きいほよ゙エントロピーは直線的に低下し ていることがわかる.なお，エントロピーは分布形が シャープなほど小さな值をとり, エントロピーの值が小 さいほど母数の推定精度が高いと判断される.

\section{（2）平均未知, 分散末知の場合}

3. では,この場合 3 通りのエントロピーを計算可能 な形に変換して示したが,ここでは平均と精度の同時事 後確率分布のエントロピーの計算結果を示す.

式（11）を計算するのに必要なパラメーターは次のよ うに与えられる.

$n^{\prime}, \alpha^{\prime}, \beta^{\prime}, \nu^{\prime}$ は事前情報であるので，すべての資料を 用いて,

$$
\begin{aligned}
& n^{\prime}=n_{\max } \\
& \alpha^{\prime}=\frac{1}{n^{\prime}} \sum_{i=1}^{n^{\prime}} x_{i} \\
& \beta^{\prime}=\frac{1}{n^{\prime}-1} \sum_{i=1}^{n^{\prime}}\left(x_{i}-\alpha^{\prime}\right)^{2} \\
& \nu^{\prime}=n^{\prime}-1
\end{aligned}
$$

と定める. また, $\bar{x}, S$ は $n$ 個の資料から計算された平 均と分散である.

図一6は，上記のように与えられたパラメーターによ り計算された結果をすべての地点について示したもので ある.エントロピーはほぼ直線的に減少しているが，そ の值や減少度合には観測所間で差がある.エントロピー 值の大小関係により観測所間の母数推定の信頼性の相対 的比較を行う場合, エントロピー値は事前情報にも依存 するため比較上最適な事前情報の与え方を検討しなけれ ばならず，図一6のエントロピー値からこの比較を論ず
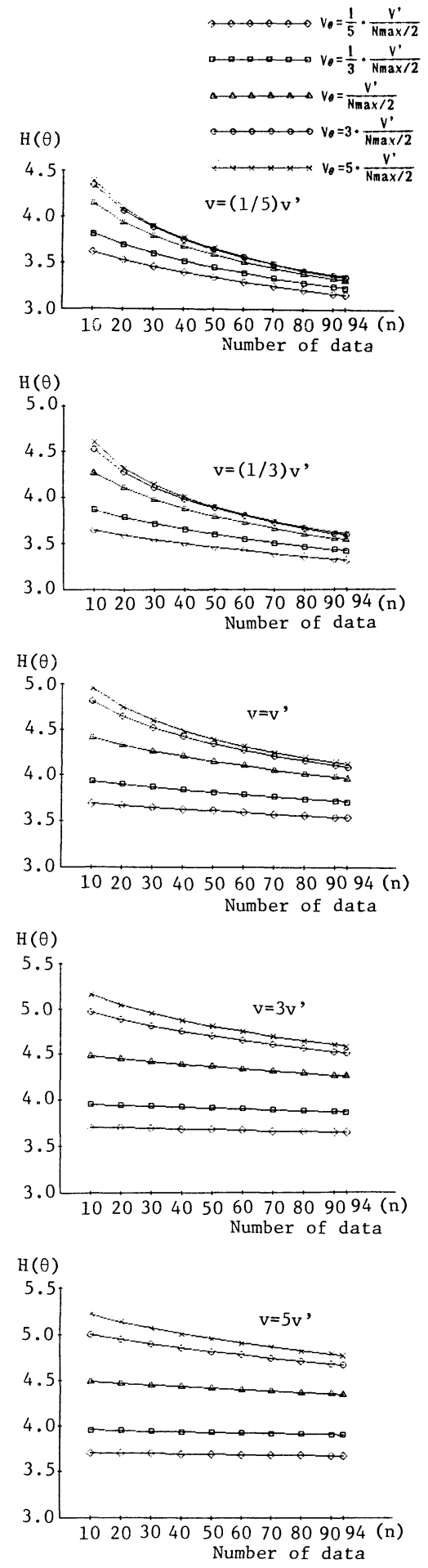

Fig. 5 Change of entropy in connection with the distribution of population parameter (Nagano) ( $\theta=$ unknown, $v=$ known). 

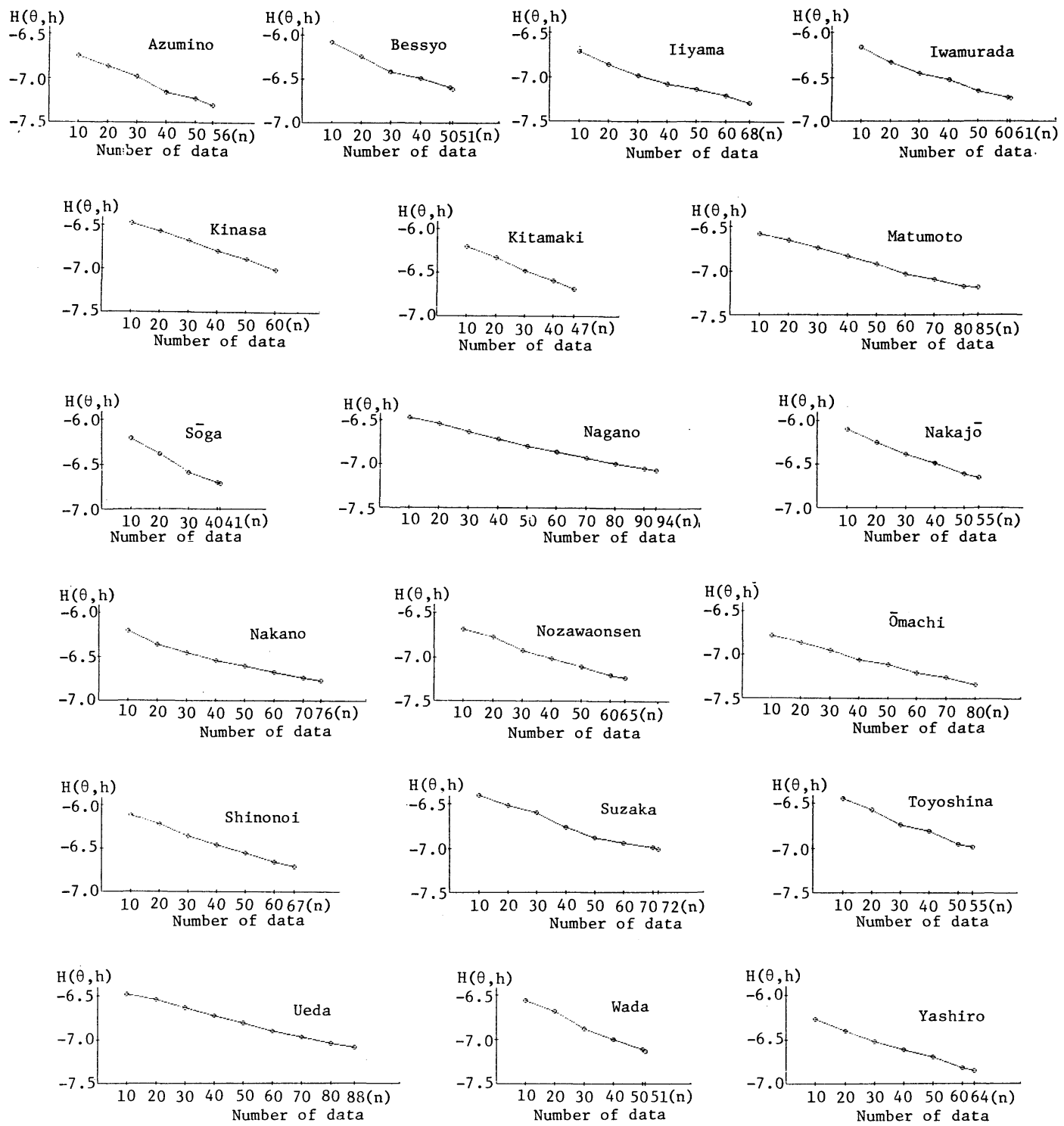

Fig. 6 Change of entropy in connection with the distribution of population parameters ( $\theta=$ unknown, $v=$ unknown).

ることは難しい. しかし，連続変数の分布の 2 つのエン トロピーの差, すなわちエントロピーがどの程度変化し たかを示す量は情報量であるから，折れ線の傾きが途中 で急になる場合には，そのとき増加させた資料はそれ以 前の状態に与える情報量が多かったことを示しており， 傾きが䋸やかなところでは増加させた資料の情報量が少 なく，あまり有効でなかったことを示している.

\section{5. 非正規母集団への適用性について}

3. では，正規情報が利用可能な場合，すなわち，基 礎確率変数が正規分布に従う場合に，母数の事前確率分 布を共役事前確率法則 (基礎確率変数の密度関数から計
算された尤度関数を密度関数のもつ母数の関数とみな し，その尤度関数から母数と母数に関する十分統計量の 項をとり出して構成された母数に関する確率密度関数を 共役事前確率法則という) で与えることにより, ベイズ 論的立場から事後確率分布を計算し, 推定母数の不確定 性を事後確率分布のエントロピーで評価した。このよう な立場から母数の不確定性を議論する場合, 基礎確率変 数に応じた母数の事前分布が与えられる必要がある.

水文頻度解析によく用いられる確率分布のうち, 母数 の共役分布が求められているものに次のものがあり, 基 礎確率変数の密度関数を $f_{x}(x)$ で表わし, 共役分布を末 知母数のサフィックスを付けて $f_{\Lambda}(\lambda)$ と示しておく ${ }^{12)}$. 
i）基礎確率変数が指数分布の場合

$f_{x}(x)=\lambda \exp (-\lambda x)$

$f_{A}(\lambda)=\nu(\nu \lambda)^{k-1} \exp (-\nu \lambda) / \Gamma(k)$

ここで, $\nu, k$ は既知とする.

ii）基礎確率変数が対数正規分布の場合

$f_{x}(x)=\frac{1}{(2 \pi)^{1 / 2} \zeta x} \exp \left\{-\frac{1}{2}\left(\frac{\ln x-\lambda}{\zeta}\right)^{2}\right\}$

ここで，とは既知とする。

$$
f_{\Lambda}(\lambda)=\frac{1}{(2 \pi)^{1 / 2} \sigma} \exp \left\{-\frac{1}{2}\left(\frac{\lambda-\mu}{\sigma}\right)^{2}\right\} \ldots
$$

ここで， $\sigma, \mu$ は既知とする.

このように，基礎確率変数が指数分布や対数正規分布 に従う場合，式 (20)，(22）を事前確率分布として事後 確率分布を計算し, 推定母数の不確定性をエントロピー で測ることができる.

基礎確率変数が，グンベル分布，ガンマ分布，あるい はわれわれが研究してきた最大エントロピー分布等をと る場合, 著者達の知るかぎり今のところ母数の事前確率 分布として有用な共役分布が明らかにされていない。こ のような場合，事前確率分布として一様分布を仮定する ことにより同様な理論展開が行われ得るが，その妥当性 については議論の余地がある。

\section{6. 結 論}

本稿では, 確率水文量の不確定性のうち推定母数の不 確定性に着目し, 資料数の増加に伴う不確定性の減少を エントロピーを用いて表現することを試みた。結果を要 約すると次のとおりである。

（1） 正規分布，グンベル分布の変動は，資料数が 30 個ないし 40 個程度までかなり大きく不安定である が，それらを越えると相対的に安定してくることがわ かった。

（2）正規分布，グンベル分布から計算される確率水 文量の変動は, 資料数が 40 個ないし 50 個程度から, 振 動しながらも一定值に収束していくことがわかった。

（３）正規分布の推定母数の不確定性は，平均未知, 分散既知の場合の平均に関する事後確率分布, 平均, 分 散ともに未知の場合の平均之精度の同時事後確率分布, 平均に関する周辺事後確率分布，精度に関する周辺事後 確率分布のエントロピーを測ることにより定式化した。

（4）平均未知, 分散既知の場合の実測資料への適用 の結果，ゼの地点でも $v_{\theta}$ および $v$ の值が大きいほどエ ントロピーの值は大きくなり, 資料数が小さいほどエン トロピーの低下分が大きくなっていることがわかった。 また， $v_{\theta}$ が小さく $v$ が大きいほどエントロピーは直線 的に低下していることもわかった。

（5）平均, 分散ともに末知の場合の平均と精度の同
時事後確率分布のエントロピー式を実測資料へ適用した 結果，エントロピーは資料数に比例してほぼ直線的に減 少しているが，その值や減少度合には観測所間で差異を 生じることがわかった。

（6）非正規母集団への適用性については，今のとこ ろ基礎確率変数が指数分布をする場合と対数正規分布を する場合について母数の事前確率分布として有用な共役 分布が知られており，本稿での議論が適用可能であるこ とを示した。

なお，本研究を行うにあたり，計算等で信州大学大学 院工学研究科学生 上原 剛君の協力を得たことを記し, 謝意を表する．また，計算にあたって，信州大学情報処 理センターHITAC M-240Hを使用した.

補遺 1。式 (11) の誘導

$$
\begin{aligned}
H(\theta, h)= & -\int_{0}^{\infty} \int_{-\infty}^{\infty} \frac{n^{\prime \prime 1 / 2}}{(2 \pi)^{1 / 2}} \frac{1}{\Gamma\left(\nu^{\prime \prime} / 2\right)}\left(\frac{1}{2} \beta^{\prime \prime} \nu^{\prime \prime}\right)^{\nu^{\prime \prime} / 2} \\
& \cdot \exp \left\{-\frac{1}{2} n^{\prime \prime} h\left(\theta-\alpha^{\prime \prime}\right)^{2}\right\} \\
& \cdot \exp \left(-\frac{1}{2} \beta^{\prime \prime} \nu^{\prime \prime} h\right) h^{\left(\nu^{\prime \prime}-1\right) / 2} \\
& \cdot \ln \left[\frac{n^{\prime \prime 1 / 2}}{(2 \pi)^{1 / 2}} \frac{1}{\Gamma\left(\nu^{\prime \prime} / 2\right)}\left(\frac{1}{2} \beta^{\prime \prime} \nu^{\prime \prime}\right)^{\nu^{\prime \prime} / 2}\right. \\
& \cdot \exp \left\{-\frac{1}{2} n^{\prime \prime} h\left(\theta-\alpha^{\prime \prime}\right)^{2}\right\} \\
& \left.\cdot \exp \left(-\frac{1}{2} \beta^{\prime \prime} \nu^{\prime \prime} h\right) h^{\left(\nu^{\prime \prime}-1\right) / 2}\right] d \theta d h \cdots \cdots .(23)
\end{aligned}
$$

ここで,

$$
\begin{aligned}
& A=\frac{n^{\prime \prime 1 / 2}}{(2 \pi)^{1 / 2}} \frac{1}{\Gamma\left(\nu^{\prime \prime} / 2\right)}\left(\frac{1}{2} \beta^{\prime \prime} \nu^{\prime \prime}\right)^{\nu^{\prime \prime} / 2} \\
& B=\left(\nu^{\prime \prime}-1\right) / 2, \quad C=\beta^{\prime \prime} \nu^{\prime \prime} / 2, \quad S=n^{\prime \prime} / 2
\end{aligned}
$$

とおくと,

$$
\begin{aligned}
H(\theta, h)= & -\int_{0}^{\infty} \int_{-\infty}^{\infty} A \exp (-C h) \exp \left\{-S h\left(\theta-\alpha^{\prime \prime}\right)^{2}\right\} h^{B} \\
& \cdot\left(\ln A-C h-S h\left(\theta-\alpha^{\prime \prime}\right)^{2}+B \ln h\right\} d \theta d h \\
= & -(\ln A) I_{\theta h}+A C J_{\theta h}+A S K_{\theta h}-A B L_{\theta h}
\end{aligned}
$$

ここで,

$$
\begin{aligned}
I_{\theta h} & =\int_{0}^{\infty} \int_{-\infty}^{\infty} A \exp (-C h) \exp \left\{-S h\left(\theta-\alpha^{\prime \prime}\right)^{2}\right\} h^{B} d \theta d h \\
& =1 \\
J_{\theta h} & =\int_{0}^{\infty} \int_{-\infty}^{\infty} \exp (-C h) \exp \left\{-S h\left(\theta-\alpha^{\prime \prime}\right)^{2\}} h^{B+1} d \theta d h\right. \\
& =\frac{\pi^{1 / 2}}{S^{1 / 2}} \int_{0}^{\infty} \exp (-C h) h^{B+\frac{1}{2}} d h=\frac{\pi^{1 / 2}}{S^{1 / 2}} \frac{\Gamma(B+3 / 2)}{C^{B+3 / 2}}
\end{aligned}
$$

$$
\begin{aligned}
K_{\theta h}= & \int_{0}^{\infty} \int_{-\infty}^{\infty} \exp (-C h) \exp \left\{-S h\left(\theta-\alpha^{\prime \prime}\right)^{2}\right\} h^{B+1} \\
& \cdot\left(\theta-\alpha^{\prime \prime}\right)^{2} d \theta d h=\frac{1}{2} \frac{\pi^{1 / 2}}{S^{3 / 2}} \int_{0}^{\infty} \exp (-C h) h^{B-1 / 2} d h
\end{aligned}
$$




$$
\begin{aligned}
= & \frac{1}{2} \frac{\pi^{1 / 2}}{S^{3 / 2}} \frac{\Gamma(B+1 / 2)}{C^{B+1 / 2}} \cdots \cdots \cdots \cdots \cdots \cdots \cdots \cdots \cdots \cdots \cdots \cdots \cdots \cdots \cdots \cdots \cdots \cdots \\
L_{\theta h}= & \int_{0}^{\infty} \int_{-\infty}^{\infty} \exp (-C h) \exp \left\{-S h\left(\theta-\alpha^{\prime \prime}\right)^{2}\right\} h^{B} \\
& \cdot \ln h d \theta d h=\frac{\pi^{1 / 2}}{S^{1 / 2}} \int_{0}^{\infty} \exp (-C h) h^{B-1 / 2} \ln h d h \\
= & \frac{\pi^{1 / 2}}{S^{1 / 2}} \frac{1}{C^{B+1 / 2}} \Gamma\left(B+\frac{1}{2}\right)\left\{\psi\left(B+\frac{1}{2}\right)-\ln C\right\}
\end{aligned}
$$

式 (26)，(27)，(28)，（29）を式（25）に代入して整 理すると,

$$
\begin{aligned}
& H(\theta, h)=-\ln A+\frac{\pi^{1 / 2} A \Gamma\left(B+\frac{1}{2}\right)}{S^{1 / 2} C^{B+1 / 2}}\left[B \left\{1-\psi\left(B+\frac{1}{2}\right)\right.\right. \\
& +\ln C\}+1]=-\ln A+B\left\{1-\psi\left(B+\frac{1}{2}\right)\right. \\
& +\ln C\}+1
\end{aligned}
$$

\section{補遗 2. 式 (13) の誘導}

$$
\begin{aligned}
H_{\theta}(\theta)= & -\int_{-\infty}^{\infty} \frac{\nu^{\prime \prime} \nu^{\prime \prime} / 2}{B\left(1 / 2, \nu^{\prime \prime} / 2\right)}\left\{\nu^{\prime \prime}+\frac{n^{\prime \prime}}{\beta^{\prime \prime}}\left(\theta-\alpha^{\prime \prime}\right)^{2}\right\}^{-\left(\nu^{\prime \prime}+1\right) / 2} \\
& \cdot\left(\frac{n^{\prime \prime}}{\beta^{\prime \prime}}\right)^{1 / 2} \ln \left[\frac { \nu ^ { \prime \prime } \nu ^ { \prime \prime } / 2 } { B ( 1 / 2 , \nu ^ { \prime \prime } / 2 ) } \left\{\nu^{\prime \prime}+\frac{n^{\prime \prime}}{\beta^{\prime \prime}}\right.\right. \\
& \left.\left.\cdot\left(\theta-\alpha^{\prime \prime}\right)^{2}\right\}^{-\left(\nu^{\prime \prime}+1\right) / 2}\left(\frac{n^{\prime \prime}}{\beta^{\prime \prime}}\right)^{1 / 2}\right] d \theta \cdots \cdots \cdots \cdots(31)
\end{aligned}
$$

ここで,

$$
\left.\begin{array}{l}
D=\frac{\nu^{\prime \prime} \nu^{\prime \prime} / 2}{B\left(1 / 2, \nu^{\prime \prime} / 2\right)}\left(\frac{\nu^{\prime \prime}}{\beta^{\prime \prime}}\right)^{1 / 2} \\
E=\left(\nu^{\prime \prime}+1\right) / 2
\end{array}\right\}
$$

とおくと,

$$
\begin{aligned}
H_{\theta}(\theta)= & -\int_{-\infty}^{\infty} D\left[\nu^{\prime \prime}+\frac{n^{\prime \prime}}{\beta^{\prime \prime}}\left(\theta-\alpha^{\prime \prime}\right)^{2}\right]^{-E}[\ln D-E \\
& \left.\cdot \ln \left\{\nu^{\prime \prime}+\frac{n^{\prime \prime}}{\beta^{\prime \prime}}\left(\theta-\alpha^{\prime \prime}\right)^{2}\right\}\right] d \theta=-(\ln D) I_{\theta}+D E J_{\theta}
\end{aligned}
$$

ここで,

$$
\begin{aligned}
& I_{\theta}=\int_{-\infty}^{\infty} D\left[\nu^{\prime \prime}+\frac{n^{\prime \prime}}{\beta^{\prime \prime}}\left(\theta-\alpha^{\prime \prime}\right)^{2}\right]^{-E}=1 \\
& J_{\theta}=\int_{-\infty}^{\infty} \frac{\ln \left\{\nu^{\prime \prime}+n^{\prime \prime}\left(\theta-\alpha^{\prime \prime}\right)^{2} / \beta^{\prime \prime}\right\}}{\left\{\nu^{\prime \prime}+n^{\prime \prime}\left(\theta-\alpha^{\prime \prime}\right)^{2} / \beta^{\prime \prime}\right\}} d \theta
\end{aligned}
$$

式 (34)，（35）を式（33）に代入すると,

$$
H_{\theta}(\theta)=-\ln D+D E J_{\theta}
$$

\section{補遺 3. 式 (15) の誘導}

$$
\begin{aligned}
H_{h}(h)= & -\int_{0}^{\infty} \frac{1}{\Gamma\left(\nu^{\prime \prime} / 2\right)}\left(\frac{1}{2} \beta^{\prime \prime} \nu^{\prime \prime}\right)^{\nu^{\prime \prime} / 2} h^{\nu^{\prime \prime} / 2-1} \\
& \cdot \exp \left(-\frac{1}{2} \beta^{\prime \prime} \nu^{\prime \prime} h\right) \ln \left\{\frac{1}{\Gamma\left(\nu^{\prime \prime} / 2\right)}\left(\frac{1}{2} \beta^{\prime \prime} \nu^{\prime \prime}\right)^{\nu^{\prime \prime} / 2}\right. \\
& \left.\cdot h^{\nu^{\prime \prime} / 2-1} \exp \left(-\frac{1}{2} \beta^{\prime \prime} \nu^{\prime \prime} h\right)\right\} d h \cdots \cdots \cdots \cdot(37)
\end{aligned}
$$

ここで,

$$
\begin{aligned}
& \begin{array}{l}
F=\frac{1}{\Gamma\left(\nu^{\prime \prime} / 2\right)}\left(\frac{1}{2} \beta^{\prime \prime} \nu^{\prime \prime}\right)^{\nu^{\prime \prime} / 2} \\
G=\nu^{\prime \prime} / 2-1
\end{array} \\
& \text { とおくと, } \\
& H_{h}(h)=-\int_{0}^{\infty} F h^{G} \exp (-C h)(\ln F+G \ln h-C h) d h \\
& =-(\ln F) I_{h}-F G J_{h}+C F K_{h} \\
& I_{h}=\int_{0}^{\infty} F h^{G} \exp (-C h) d h=1 \\
& J_{h}=\int_{0}^{\infty} h^{c} \exp (-C h) \ln h d h \\
& =\frac{\Gamma(G+1)}{C^{G+1}}\{\psi(G+1)-\ln C\} \\
& K_{h}=\int_{0}^{\infty} h^{G+1} \exp (-C h) d h=\frac{\Gamma(G+2)}{C^{G+2}}
\end{aligned}
$$

式 (40)，(41)，(42）を式 (39) に代入して整理すると,

$$
H_{h}(h)=-\ln F+G\{1-\psi(G+1)+\ln C\}+1 \cdots
$$

\section{参考 文献}

1）高棹环馬・池淵周一：エントロピー的にみた降雨・流出 変換特性とそのモデル化, 京都大学防災研究所年報, No. 23, B-2, pp. 193 209, 1980 年.

2) Sonuga, J. O. : Principle of maximum entropy in hydrologic frequency analysis, Journal of Hydrology, Vol. 17, pp. 177 191, 1972.

3) Sonuga, J. O. : Entropy principle applied to the rainfallrunoff process, Journal of Hydrology, Vol. 30, pp. 81 94, 1976.

4）寒川典昭- 荒木正夫 : 水文事象の頻度分析への MEP 導 入について, 土木学会論文報告集, No. 335, pp. 89 95, 1983 年.

5）寒川典昭 - 荒木正夫 - 小林紀之：種々の水文量への 1 変 数 MEP 分布の適用性, 信州大学工学部紀要, No. 58, pp. 27 40, 1985 年.

6) Wragg, A. and Dowson, D. C. : Fitting Continuous probability density functions over $[0, \infty)$ using information theory ideas, IEEE Transactions on Information Theory, Vol. IT-16, pp. 226 230, 1970.

7） 寒川典昭・荒木正夫 - 寺島 彰 : 2 変数 MEP 分布とそ の特性に関する研究, 水理講演会論文集, No. 28 , pp. 397 402, 1984 年.

8）寒川典昭・荒木正夫・佐藤健次：多変数最大エントロ ピー分布とその基礎特性に関する研究, 土木学会論文集 (投稿中).

9）建設省北陸地方建設局千曲川工事事務所編集：千曲川・ 犀川河川要覧 (雨量資料編), 1976 年.

10）宮沢光一：情報・決定理論序説, 岩波書店, pp. 126 150, 1971 年.

11）たとえば，大泉充郎・本多波雄・野口正一：情報理論, オーム社, p. 80, 1962 年.

12）たとえば, 伊藤 学・亀田宏行訳 : 土木・建築のための 確率 - 統計の基礎, 丸善株式会社, p. 346, 1977.

(1986.3.6 - 受付) 